\title{
МЕДИАТИЗАЦИЯ ИСТОРИИ
}

УДК 94(470.53):070

doi 10.17072/2219-3111-2019-2-76-86

\section{СТАНОВЛЕНИЕ И ФУНКЦИОНИРОВАНИЕ ПЕРВОЙ ЧАСТНОЙ ГАЗЕТЫ «ЕКАТЕРИНБУРГСКАЯ НЕДЕЛЯ» В ПЕРМСКОЙ ГУБЕРНИИ В ПОСЛЕДНЕЙ ЧЕТВЕРТИ ХІХ ВЕКА}

\section{Г. Н. Плотникова, С. Н. Плотников}

Пермский государственный национальный исследовательский университет, 614990, Пермь, ул. Букирева, 15 sgp80@yandex.ru

Анализируется процесс становления частных средств массовой информации в Пермской губернии на примере еженедельной политической и литературной газеты «Екатеринбургская неделя» (в 2019 г. исполняется 140 лет с начала ее существования). Рассматривается открытие и функционирование издания, характеризуются основные рубрики, прослеживаются взаимоотношения редакции и представителей официальной власти (губернатора, Главного управления по делам печати при МВД, департамента полиции), выявляется неоднозначная реакция общественности на опубликованную информацию. Делается вывод о том, что появление первой частной газеты оказало значительное влияние на общественность не только Екатеринбурга, но и губернии в целом. Нарабатывались и совершенствовались механизмы обратной связи с населением и органами власти. Этот процесс происходил в условиях непрерывного контроля содержания публикуемого газетой материала цензурными органами, что нередко приводило к конфликтным ситуациям с редакцией, кадровым перестановкам и смене владельцев издания. Контроль со стороны представителей властных структур также затруднял и формирование независимой позиции редакции. Серьезной проблемой была убыточность издания. При этом в качестве корреспондентов привлекались известные уральские писатели и журналисты, нередко предлагавшие читателям собственное видение актуальных проблем. Имела место и критика в адрес местных чиновников. Значительное увеличение тиража свидетельствовало о росте популярности издания. Обращаясь к жителям губернии в целом, газета носила универсальный характер. Ее деятельность стабилизировала социальнополитическую обстановку в обширном полиэтничном уральском регионе. «Екатеринбургская неделя» вовлекала читателей в публичную жизнь, занималась их просвещением, являлась важным фактором формирования социокультурной среды и гражданских начал в российской провинции в последней четверти XIX в.

Ключевые слова: СМИ, «Екатеринбургская неделя», цензура, Главное управление по делам печати, общественность, Пермская губерния последней четверти XIX в.

В современном информационном обществе актуальны проблемы открытия и функционирования независимых средств массовой информации, их отношений с обществом и властью. В силу того что большинство населения страны проживает вдали от столицы, особый интерес представляет зарождение независимой провинциальной прессы. Как известно, массовые периодические издания (официальные губернские ведомости) в российской провинции появились в первой половине XIX в., став важным фактором развития общественного сознания в переломную эпоху Великих реформ (1860-1870-х гг.).

Модернизация Российской империи, начавшаяся после отмены крепостного права, сопровождалась не только социально-экономическими изменениями, но и значительным увеличением численности населения и ростом грамотности. В первые пореформенные десятилетия появилось поколение прогрессивно мыслящих молодых людей, жаждавших знаний и желавших перемен. Возникла потребность в новых средствах массовой информации, в том числе в провинции.

Расположенная в Европе и Азии обширная Пермская губерния в рассматриваемый период состояла из двенадцати уездов, была полиэтничной и поликонфессиональной. Широкое обсуждение пермской общественностью реализации Великих реформ стимулировало появление новых

(C) Плотникова Г. Н., Плотников С. Н., 2019 
печатных изданий. В это время в губернии издавались только две официальные газеты - «Пермские губернские ведомости» (с 1838 г.) и «Пермские епархиальные ведомости» (с 1867 г.).

В 1860-1870-х гг. неоднократно предпринимались попытки создать частную газету в Перми и Екатеринбурге, втором по значимости городе Пермской губернии. В октябре 1861 г. известный общественный деятель и краевед Д.Д. Смышляев обратился в Московский цензурный комитет с просьбой о разрешении издавать еженедельную газету «Пермяк». В мае 1872 г. надворный советник А.И. Безбородов подал в Главное управление по делам печати прошение об издании в Екатеринбурге еженедельной газеты «Уральский листок». В октябре 1873 г. статский советник А.Д. Крупенин обратился с просьбой об издании в Екатеринбурге газеты «Урал». Екатеринбургский купец второй гильдии П.П. Петров в ноябре 1876 г. вновь пытался получить разрешение на издание газеты «Уральский листок». Все эти прошения были отклонены по разным причинам. В их числе недостаточный уровень образования потенциальных издателей, их неблагонадежность, отсутствие достаточных средств, неудовлетворительное содержание предложенной программы и даже склонность отдельных заявителей к употреблению алкогольных напитков.

Население Екатеринбурга, являвшегося центром горнозаводской промышленности Урала, испытывало особую потребность в местном печатном органе. Данная ситуация, характерная для большинства регионов страны, нашла отражение в целом ряде исследований. Так, информация об условиях создания и функционировании газет содержится в статьях, характеризующих как общероссийские [Глинский, 1898; Есин, 1971; Грабельников, 2000; Абросимов, Кузьмин], так и уральские периодические издания ХIX в. [Павлов, 1966, 1995, 1997; Лихтин, 2005; Барышникова, 2016]. Значительный интерес представляют работы, в которых рассматривается становление частных провинциальных газет [Кройчик, 2004; Мандрика, 2007; Буторин, 2011; Барышникова, 2016]. Взаимоотношение СМИ и власти, включая последнюю четверть XIX в., стало объектом исследования ряда авторов [Катков, 1905; Чернуха, 1992; Патрушева, 1996, 2000; Гринченко, 2009]. Непосредственно о «Екатеринбургской неделе» писала С.Я. Бугаева [Бугаева, 1998]. Она сосредоточила внимание на публикациях, посвященных горнозаводской промышленности. Отдельные сведения о повседневной жизни уральцев во второй половине XIX в., отраженные в данном издании, содержатся в статье О.В. Моревой [Морева, 2017].

Особый интерес вызывают работы В.А. Павлова [Павлов, 1995, 1997], в которых освещена история журналистики Урала XIX в. Автор, в частности, рассмотрел биографии издателей «Екатеринбургской недели», ее редакторов, цензоров, известных журналистов, сотрудничавших с газетой. Он также подробно охарактеризовал основные разделы издания, взаимоотношения редакции и цензуры. Однако его «Очерки истории журналистики Урала» [Павлов, 1995, 1997] написаны с марксистских позиций, изобилуют устаревшей терминологией («вторая революционная ситуация», «верхи», «феодально-крепостнические пережитки», «буржуазный либерализм», «пролетарское движение» и др.). В.А. Павлов называет оппозиционность земства «видимостью», что не отражает многогранности деятельности всесословных органов местного самоуправления. Автор высоко оценивает деятельность народовольцев, называет К.П. Победоносцева «мракобесом». Он критикует газету за то, что она отрицательно относилась к революционному движению, народникам, их покушениям на царя. В.А. Павлов много внимания уделяет негативному освещению в «Екатеринбургской неделе» рабочих и крестьянских волнений в крае, называет газету «сторонницей крайнего консерватизма» [Павлов, 1997, с. 10]. В то же время он пишет о том, что «переплетение элементов демократизма с преобладающим либерализмом позволило участвовать в газете людям разных идейно-политических и эстетических позиций и настроений» [Там же, с. 16]. Автора особенно привлекает литературная деятельность писателей-демократов, сотрудничавших с «Екатеринбургской неделей». Однако он практически не анализирует причины появления первой в губернии частной газеты, не рассматривает процедуру ее открытия, программу издания и условия функционирования. Кроме того, им не показана роль Н.А. Иосса в получении разрешения на издание газеты. Представляется спорным и вывод автора о том, что газета отражала и формировала «интересы крупного промышленного капитала, городской и сельской буржуазии, способствуя поступательному движению капитализма...» [Там же, с. 32].

Исходя из сказанного, цель настоящей статьи - охарактеризовать становление частных СМИ в Пермской губернии в последней четверти XIX в. по материалам газеты «Екатеринбургская неделя». 
Для достижения поставленной цели необходимо рассмотреть процесс становления издания, проанализировать его основные рубрики, взаимоотношения редакции газеты и представителей властных структур (губернатора, Главного управления по делам печати при МВД ${ }^{1}$, департамента полиции ${ }^{2}$ ), а также реакцию общественности на публикуемую информацию.

В качестве методологической основы исследования использован институциональный подход, позволяющий рассматривать становление частных СМИ как процесс формирования нового элемента социальной структуры, регламентированного правовыми нормами и осуществляющего многосторонний обмен информацией. Исходя из данного подхода, анализируется деятельность «Екатеринбургской недели», взаимоотношения редакции газеты и представителей властных структур, общественности.

В статье наряду с публикациями в «Екатеринбургской неделе» использованы материалы фондов канцелярии Главного управления по делам печати и департамента полиции Министерства внутренних дел Российской империи, хранящиеся в РГИА. Отдельную группу источников составили нормативно-правовые акты, регулирующие открытие и деятельность СМИ в рассматриваемый период, в том числе частных изданий (Высочайше утвержденные..., 1862; О даровании..., 1867; Высочайше утвржденные..., 1886).

Инициатором издания первой на Урале частной городской газеты «Екатеринбургская неделя» стал горный инженер коллежский советник Николай Алексеевич Полков. По его замыслу газету предполагалось издавать в первую очередь для работников горнозаводской промышленности, которая находилась в состоянии кризиса. «Екатеринбургская неделя» должна была обратить внимание на проблемы этой отрасли и способствовать повышению ее авторитета. Восемнадцатого августа 1877 г. Н.А. Полков обратился в Главное управление по делам печати с просьбой разрешить издавать еженедельную газету и утвердить его главным редактором.

Процедура учреждения газеты была довольно сложной. Сначала необходимо было получить разрешение губернатора, затем одобрение III отделения собственной Его Императорского Величества канцелярии, Главного управления по делам печати и, наконец, министра внутренних дел. Открытию газеты способствовали личные связи и протекция Н.А. Иосса ${ }^{3}$, известного столичного горного инженера, выходца из Пермской губернии. Именно к нему обратился за помощью Н.А. Полков (РГИА. Ф. 945. Оп. 1. Д. 127. Л. 1). По запросу Главного управления по делам печати пермский губернатор Н.Е. Андреевский в сентябре 1877 г. дал положительную характеристику Н.А. Полкову и обещал не препятствовать его ходатайству. 23 октября того же года III отделение сообщило об отсутствии претензий и препятствий к тому, чтобы Н.А. Полков издавал и редактировал газету. 9 ноября 1877 г. Главное управление по делам печати обратилось в МВД с просьбой разрешить печатать газету в Екатеринбурге, так как этот город занимал видное место среди губернских городов и в нем действительно ощущалась потребность в местном печатном органе. В итоге 25 января 1878 г. разрешение было получено. Его условием было ограничение содержания материалов «регионом Пермской губернии» (РГИА. Ф. 776. Оп. 6. Д. 190. Л.7-9). Н.А. Полков был утвержден главным редактором и сразу же напечатал объявление, в котором от имени редакции будущего издания приглашал всех желающих присылать сообщения и статьи по вопросам общественной жизни, городского, земского и горнозаводского хозяйства, а также беллетристику.

Первоначально согласно утвержденной МВД программе в «Екатеринбургской газете» разрешалось печатать краткие сообщения на политические темы из правительственных и подцензурных повременных изданий, указы и распоряжения, касающиеся Пермской губернии. Кроме того, планировалось публиковать обзоры деятельности и распоряжения губернских и уездных земских учреждений, а также казенных и частных горных заводов губернии. В газете также предполагалось освещать внутреннюю хронику г. Перми, публиковать повести и рассказы, стихи, казенные и частные объявления (РГИА. Ф. 776. Оп. 6. Д. 190. Л. 17).

Однако по просьбе главного редактора программа газеты была расширена. Ее разрешалось дополнить публикацией телеграмм правительства и международного телеграфного агентства. Предполагалось также печатать финансово-экономические обозрения горного промысла России, хронику города Екатеринбурга (деятельность городового управления, театра, судебных учреждений и общественности), обозрения столичной и провинциальной периодики, переводные стихи, 
повести и рассказы, а также статьи по воспитанию, народному образованию и гигиене (РГИА. Ф. 776. Оп. 6. Д. 190. Л. 21).

Издание подлежало цензуре. Губернатор должен был назначить цензора. Статьи в газете могли публиковаться под псевдонимом, но редакция должна была знать настоящее имя автора, его должность (звание) и место жительства. В противном случае статьи не печатались. Редакция оставляла за собой право сокращать и изменять содержание присылаемых материалов (РГИА. Ф. 945. Оп. 1. Д. 127. Л. 1).

Просьба Полкова утвердить вторым редактором газеты выходца из купцов А.А. Клопова, получившего юридическое образование в Московском университете, была отклонена III отделением ввиду его неблагонадежности. Вскоре Н.А. Полков умер, и право на издание газеты перешло его жене А.А. Полковой. Однако редактировать издание ей не было разрешено. Лишь в июне 1879 г. редактором газеты был утвержден главный механик уральских заводов П.К. Штейнфельд, близкий друг Н.А. Полкова. Вторым редактором стал коллежский советник мировой судья Верхотурского уезда А.Н. Супонев, которого в октябре 1882 г. сменил В.Н. Мылов, бывший цензор газеты, старший лесничий екатеринбургских заводов. А.А. Полкова вместе со своей золовкой Е.А. Полковой для издания газеты были вынуждены открыть собственную типографию.

«Екатеринбургская неделя» начала издаваться с июля 1879 г. и выходила до конца 1896 г. Ежегодно (кроме первого года) печатали по 50 номеров. Отдельно выходили приложения к газете. В качестве примеров приложений можно привести «Прибавления на время Сибирско-Уральской научно-промышленной выставки 1887 г.», «Записки Уральского общества любителей естествознания (1883-1896 гг.)», литературный отдел «Неделя» (1886, 1892, 1893 гг.) и др.

Одним из источников дохода частного издания являлись платные рекламные и другие объявления, которые можно было послать в редакцию, расположенную по улице Васнецовской в доме А.А. Полковой. Начиная с 1880 г. объявления для размещения в «Екатеринбургской неделе» можно было подать также в Москве и Казани. В 1882 г. газета имела 674 годовых подписчика (из них 96 с рассрочкой платежа) и 59 полугодовых (РГИА. Ф. 776. Оп. 6. Д. 190. Л. 112). В 1890 г. их насчитывалось уже 1100. В розничной продаже за неделю расходилось примерно 10 экземпляров. Несмотря на то, что стоимость подписки росла, газета вскоре стала убыточной и в июне 1883 г. А.А. Полкова передала право издания газеты главному редактору П.К. Штейнфельду. Он обратился в Главное управление по делам печати с просьбой разрешить издавать газету два-три раза в неделю и выпускать литературные приложения. Однако это ходатайство было отклонено.

Наиболее видными корреспондентами газеты были писатель Д.С. Мамин-Сибиряк, сторонник развития местной прогрессивной печати, и служащий пермской казенной палаты И.Г. Остроумов. Д.С. Мамин-Сибипяк в 1886 г. опубликовал очерк «Кризис уральской горнопромышленности». Он писал преимущественно об актуальных проблемах развития края. И.Г. Остроумов в 18881892 гг. напечатал библиографические заметки «К изучению Пермской губернии». Тесно сотрудничал с изданием житель Екатеринбурга В.А. Весновский. В своих статьях он рассуждал о городском благоустройстве и был активным сторонником открытия в городе политехникума. Корреспондентами газеты являлись также врач Д.П. Никольский, экономист И.С. Сигов и др. Журналисты пропагандировали развитие науки и выступали за модернизацию уральской горнозаводской промышленности. Корреспонденты «Екатеринбургской недели» первыми подняли проблему истребления лесов, загрязнения рек и атмосферы края в связи с деятельностью промышленных предприятий. Наибольшей популярностью газета пользовалась в то время, когда ее редактором был известный саратовский писатель, журналист и поэт П.Н. Галин (1886-1896). Он публиковал свои стихотворения под псевдонимом «дядя Листар». Издатели «Екатеринбургской недели» практиковали материальное стимулирование авторов публикаций. В редакции имелась расчетная гонорарная книга, в которой корреспонденты расписывались за полученные гонорары.

Газета пользовалась популярностью не только в кругу интеллигенции города, но и среди заводских рабочих и сельского населения. Публикуемые материалы отвечали интересам широкой читательской аудитории. Под рубрикой «Действия и распоряжения правительства» в ней печатались циркуляры министров, указы Правительствующему сенату и определения Святейшему синоду. В другом разделе описывалась деятельность уральских горных заводов, публиковались статьи по экономике, статистике и сельскому хозяйству края (сведения о почвах, посевах, семейных разделах крестьян, кустарных промыслах, сельскохозяйственные бюллетени). Отдельно печатались 
материалы о народном образовании, медицине и санитарии (посвященные преимущественно деятельности земских служащих). В каждом номере газеты публиковались корреспонденции из различных уездов Пермской губернии, из других губерний, а также выдержки из столичных газет и журналов, содержащие новости о внутренней и внешней политике Российской империи. Один раздел газеты был отведен для фельетонов и других литературных произведений. В издании также печатались исторические очерки. В газете помещались некрологи и письма в редакцию. Рекламы, объявления, извещения занимали от четырех до шестнадцати страниц. Большинство публикаций не было подписано фамилиями авторов, статьи подписывались, как правило, одной буквой или псевдонимом.

Большое внимание авторы публикаций уделяли реформам 1860-1870-х гг., отмечая их положительные и отрицательные последствия. Несмотря на положительную в целом оценку Великих реформ, корреспонденты газеты нередко печатали и критические заметки. Так, один из них в статье «Штрихи общественной жизни» иронично писал о том, что дореформенному периоду в Пермской губернии можно присвоить девиз «в Перми все можно», а пореформенному - «кое-что можно, да не все» (Штрихи общественной жизни, 1879, № 9, 19 сентября, с. 100). Подчеркивая неудовлетворенность преобразованиями первых лет после отмены крепостного права, другой автор отмечал, что и на рубеже 1870 и 1880-х гг. «все ждут реформ и исправления по всем отраслям управления» (Вести отовсюду, 1880, № 49, 10 декабря, с. 791). Корреспонденты писали о тяжелом положении крестьян в разных уездах губернии, плохих почвах, низких урожаях, высоких налогах, нищете и социальном расслоении (Корреспонденции Екатеринбургской недели, 1880, № 21, 27 мая, c. 345-346).

Критикуя деятельность пермского земства в стихотворной форме, автор, подписавшись «первый земщины боец», сообщал о расхищении казенных средств во время ремонта Сибирского тракта, намекая на причастность к этому председателя пермской губернской земской управы Д.Д. Смышляева (Штрихи общественной жизни, 1879, № 1, 25 июля, с. 8). Эта проблема, затронутая уральской газетой, несколькими месяцами ранее была поднята в столичной печати (Шашков, 1879). Особенно резкой критике подвергалась деятельность земских учреждений в области народного образования и здравоохранения. Корреспонденты были возмущены высокой детской смертностью в крае, плохим медицинским обслуживанием, нехваткой фельдшеров и аптек. Сравнивая данные о школах в США, Швейцарии и Пермской губернии, один из авторов пришел к выводу о том, что всегда выигрывает «тот народ, который имеет лучшие школы» (Пермское губернское..., 1884, № 7, 15 февраля, с. 129). В газете регулярно публиковались протоколы заседаний уездных земских собраний, статистические исследования, известия об открытии земских школ, больниц. Много внимания в издании уделялось хозяйственной деятельности в крае городских дум. Поздравляя представителей местного самоуправления с новогодними праздниками, корреспонденты предлагали им быть публичными, не бояться обсуждать с избирателями злободневные проблемы (Наши новогодние..., 1880, № 1, 2 января, с. 10). В рассказе о строительстве в губернии железной дороги были отмечены не только положительные (приобщение к Европе), но и отрицательные последствия этого для крестьян Чердынского уезда. Железная дорога и связанная с ней разработка каменного угля в Луневских копях лишали их основного заработка - заготовки дров и строевого леса для соляных промыслов (Пермь, 1879, № 10, 26 сентября, с. 116). Корреспонденты газеты выступили сторонниками строительства в крае рельсового завода. Издание уделяло большое внимание состоянию горнозаводской промышленности. Корреспонденты критиковали заводчиков за постоянное обращение за помощью к правительству, называя их «государственными нищими» (Несколько слов..., 1880, № 1, 2 января, с. 3). Они выступали за модернизацию производства. В газете публиковались очерки по истории отдельных заводов края (Невьянского, Каменского и др.). Критикуя деятельность министров, один из авторов предлагал созвать уполномоченных с мест для участия в земском соборе, чтобы довести до царя мнение народа о деятельности правительства. Таким образом, «Екатеринбургская газета» являлась и своеобразной трибуной, с которой звучали критические голоса пробуждающейся к гражданской жизни провинциальной общественности.

В газете нередко публиковались материалы о злоупотреблениях чиновников, имевшие широкий общественный резонанс. Ярким примером этого стала заметка станового пристава В.А. Бойкова. В ней сообщалось о запрещении управляющим Сысертскими горными заводами В.А. Черкасовым использовать заводских лошадей фельдшерами для обслуживания населения. При 
этом возникла проблема объективности напечатанного материала. В корреспонденции говорилось о том, что общественность потребовала не только отменить запрет на использование лошадей, но и отстранить от управления заводами В.А. Черкасова (Бойков, 1884, № 7, 15 февраля, с. 134-137). Последний был возмущен публикацией неверной информации и подал на редакцию газеты в суд. Кроме того, он обратился с жалобой в Главное управление по делам печати. Материалы газеты, по его мнению, содержали оскорбление, клевету, ложь и разжигание «антагонизма мелких партий» (РГИА. Ф. 776. Оп. 6. Д. 190. Л. 144). В итоге становой пристав В.А. Бойков был уволен, а рецензирование газеты передано другому чиновнику по требованию начальника Главного управления по делам печати Е.М. Феоктистова, которому регулярно сообщали о появлении в газете материалов тенденциозного характера.

Жители города неоднократно возмущались публикацией сведений, «касающихся домашней жизни частных лиц», считая их оскорбительными (РГИА. Ф. 776. Оп. 6. Д. 190. Л. 147). На клевету, содержащуюся в материалах газеты, жаловался уездный гласный почетный гражданин купец Н.Г. Стрижев. Жалобы, поступавшие в Главное управление по делам печати, вынуждали Е.М. Феоктистова вести переписку с пермским губернатором А.К. Анастасьевым и директором департамента полиции П.Н. Дурново (РГИА. Ф. 776. Оп. 6. Д. 190. Л. 169об.-170). В письмах губернатору Феоктистов просил присылать ему все номера издания и требовал строже наблюдать за газетой. Поводом к этому послужило донесение начальника пермского губернского жандармского управления полковника И.А. Ордынского директору департамента полиции П.Н. Дурново. В нем сообщалось о том, что в «Екатеринбургской неделе» за 23 января 1885 г. была опубликована статья, в которой обличались злоупотребления министров и указывались их отдельные недостатки. Автором ее, как выяснилось, являлся П.А. Найданов, состоявший под негласным надзором полиции (РГИА. Ф. 102. Оп. 1885. Д. 164. Л. 1). В силу этого Е.М. Феоктистов назвал общее направление газеты «крайне предосудительным». Он предложил передать осуществление ее цензуры в Москву или Казань (по усмотрению МВД). На это решение последовала бурная реакция общественности, которая ходатайствовала о возвращении цензуры в Екатеринбург. С такой просьбой от имени общественности 14 мая 1885 г. в Главное управление по делам печати обратился городской голова И.И. Симонов. Он аргументировал свою просьбу тем, что между городской думой, земствами уезда, губернской администрацией и редактором установилось полное взаимопонимание, поэтому данные учреждения находят значительную поддержку газеты в осуществлении связей с общественностью. Перенос цензуры в другой город мог нарушить эту связь. Инициатива общественности была поддержана и пермским губернатором А.К. Анастасьевым. В итоге Главное управление удовлетворило просьбу с условием, что передовые статьи должны проходить цензуру в Перми, а все прочие - в Екатеринбурге. При этом цензорами должны были назначаться лица, знакомые с цензурным уставом. Тем не менее, нарушения фиксировались и после этого.

Устав бороться, П.К. Штейнфельд в октябре 1885 г. продал газету коллежскому советнику Г.А. Тиме. В том же году А.А. Полкова продала Г.А. Тиме и типографию. В.Н. Мылов же отказался от должности второго редактора, на которую был назначен А.М. Симонов. В июне 1886 г. вторым редактором стал почетный гражданин города П.Н. Галин. В октябре 1886 г. Г.А. Тиме продал газету и типографию А.М. Симонову (РГИА. Ф. 776. Оп. 6. Д. 190. Л. 218).

Недовольство чиновников Главного управления по делам печати и некоторых читателей вызывали публикации и в других разделах «Екатеринбургской недели», включая сообщения из-за рубежа. Под рубрикой «За границей» анализировались международные отношения, сообщалось о недовольстве рабочих в Италии и положении налогоплательщиков в разных, преимущественно европейских, странах. Печатались материалы о распространении анархистских листков среди рабочих и покушениях анархистов во Франции, Италии, Англии. В связи с завершением Русскотурецкой войны 1877-1878 гг. на страницах газеты широко обсуждался вопрос о выплате пособий семьям погибших военнослужащих. Публиковались также материалы о японско-китайской войне 1894-1895 гг., о постановке Россией вопроса об улучшении быта армян, европейском «больном человеке» (Турции), об усилении на Дальнем Востоке Японии и т.п. Большой резонанс имела статья о признании гражданского брака равным церковному в Австро-Венгрии.

Подобные публикации также вызывали неоднозначную реакцию читателей, следствием которой были новые жалобы в Главное управление по делам печати. Член совета этого управления действительный статский советник Н.Н. Новиков упрекал корреспондентов в размещении в газете 
материалов о гражданском браке в Австро-Венгрии. Он возмущался отрицательным отношением к деятельности западноевропейских правительств, глав государств, их налоговой политике. По его мнению, это могло породить у читателей нездоровое отношение и к деятельности российского правительства (РГИА. Ф. 776. Оп. 6. Д. 191. Л. 56).

В литературном отделе газеты наряду с А.П. Чеховым, И.С. Тургеневым, В.Г. Короленко печатались уральские авторы (Д.Н. Мамин-Сибиряк, А.А. Кирпищикова, А.С. Сигов и др.). Кроме того, публиковались переводы Э. Золя, Г. Мопассана, Т. Гросса и др.

Большой интерес и неоднозначное понимание не только у рядовых читателей, но и у представителей власти вызывала публикация некоторых художественных произведений и фельетонов. Так, в феврале 1884 г. широкий общественный резонанс имел фельетон в стихах, в котором описывалась жизнь попа Митрофана, погрязшего в пьянстве, стяжательстве и грубом насилии. Публикация фельетона возмутила и Е.М. Феоктистова. Критика священнослужителя шла вразрез с проводившейся в эпоху правления Александра III официальной политикой, направленной на повышение авторитета и роли церкви в жизни российского общества.

В рассказе Елизаветы Головой «Новый год» повествовалось о полных грусти и сожалений воспоминаниях арестованного революционера, заключенного в одиночную камеру (Голова, 1889, № 50, 31 декабря, с. 1095-1097). Публикация настолько возмутила Феоктистова, что он был вынужден обратиться к пермскому губернатору В.В. Лукошкову с просьбой наказать виновных. В итоге цензор рассказа екатеринбургский полицмейстер барон фон Таубе получил выговор и предупреждение. Рассказ «Разрыв», напечатанный в газете в декабре 1894 г. (Разрыв, 1894, № 49, 11 декабря, с. 1023), вынес на суд общественности семейные отношения (проблему женской эмансипации), что, по мнению Н.Н. Новикова, было недопустимо. В апреле 1895 г. в «Екатеринбургской неделе» был опубликован переведенный с немецкого языка В. Идельсоном рассказ Т. Гросса «Кубарь, или бухгалтерия на том свете». В нем есть разговор немецкого графа с апостолом Петром (Гросс, 1895, № 14, 9 апр., с. 301-303). Н.Н. Новиков усмотрел в нем «злоумышленную карикатуру на первоверховного апостола, высмеивание всего христианского учения, священного писания» (РГИА. Ф. 776. Оп. 12. Д. 61. Л. 71 об.). Член совета считал, что это играет на руку атеистам и анархистам. В письме пермскому губернатору он назвал рассказ «санкцией разврата и преступности», «безобразным вымыслом, памфлетом», «зловредным пасквилем, рассчитанным на невежество начинающих читателей» (РГИА. Ф. 776. Оп. 12. Д. 61. Л. 72). Жалоба Н.Н. Новикова пермскому губернатору П.Г. Погодину вызвала острую полемику, в которую включился редактор газеты П.Н. Галин. Он признал данный рассказ не только нравственным, но и поучительным, сравнив его с широко известным произведением В.Г. Короленко «Сон Макара».

Подобные конфликтные ситуации возникали регулярно на протяжении всего периода существования газеты. Они приводили к смене владельцев издания, кадровым перестановкам, тем самым осложняя работу газеты, способствуя ее закрытию. В результате в мае 1896 г. издание «Екатеринбургской недели» перешло от А.М. Симонова к статскому советнику В.Г. Чекану, при этом П.Н. Галин оставался ответственным редактором до ноября 1896 г. С января 1897 г. вместо «Екатеринбургской недели» В.Г. Чекан получил право издавать новую газету «Урал».

Таким образом, издание «Екатеринбургской недели» стало первым опытом становления и функционирования в Пермской губернии нового социального института - частных СМИ. Этот опыт был неоднозначным. С одной стороны, работа газеты встречала множество препятствий со стороны чиновников Главного управления по делам печати, департамента полиции и администрации пермского губернатора. Просматривая каждый номер газеты, они отслеживали информацию, которая, по их мнению, шла вразрез с государственной политикой и могла дурно повлиять на общественность. Это мешало формированию независимой позиции редакции. Кроме того, издание частной газеты требовало значительных средств. В силу того что большинство ее читателей были людьми небогатыми, газета оставалась убыточной. С другой стороны, приобретались навыки руководства новым видом периодического издания, создавались механизмы обратной связи с общественностью и органами власти, что, безусловно, стабилизировало социально-политическую обстановку в регионе. Прогрессивно мыслящие корреспонденты (редакция привлекла в этом качестве известных уральских писателей и журналистов) не только поднимали острые проблемы, волновавшие жителей края, но и нередко выражали собственную независимую позицию. В «Екатеринбургской неделе» публиковались материалы, затрагивающие проблемы эмансипации женщин, равен- 
ства церковного и гражданского брака, доступности образования и медицинского обслуживания в крае, высокой детской смертности. Нередко появлялись критические замечания о чиновниках, деятельности органов местного самоуправления, заводской администрации. Читатели знакомились с произведениями не только отечественных, но и зарубежных авторов, аннотациями новых книг и книжными обозрениями, что, безусловно, расширяло их кругозор. Общественность бурно реагировала на злободневные публикации. Издание было популярным, о чем свидетельствует почти двукратный рост его тиража. «Екатеринбургская неделя» носила универсальный характер, так как редакция обращалась не только к горнозаводским служащим и рабочим, но и к жителям региона в целом. Отражая повседневную жизнь населения губернии, состояние провинциального общества, газета занималась просвещением жителей края, вовлечением читателей в публичную жизнь. Частному периодическому изданию отводилась важная роль в формировании социокультурной среды в провинции. В условиях дефицита в стране (за исключением столиц) средств массовой информации и ужесточения цензуры в царствование Александра III первая в Пермской губернии частная газета «Екатеринбургская неделя» оставалась одним из основных информационных источников и способствовала развитию в российской провинции начал гражданского общества.

\section{Примечания}

${ }^{1}$ В результате цензурной реформы 1865 г., проведенной с целью централизации контроля за СМИ, было создано Главное управление по делам печати МВД. В исследуемый период этим ведомством руководили В.В. Григорьев (1875-1880), Н.С. Абаза (1880-1881), П.П. Вяземский (1881-1883) и Е.М. Феоктистов (1883-1896). В 1882 г. были приняты новые временные правила о печати, согласно которым давление на частную периодику было усилено.

${ }^{2}$ В 1880 г. было упразднено III отделение и в целях централизации управления создан Департамент полиции при МВД, одной из функций которого был надзор за печатью.

${ }^{3}$ В личном фонде Н.А. Иосса имеются письма, адресованные ему Н.А. Полковым, с просьбой о содействии изданию «Екатеринбургской недели»..

\section{Список источников}

Бойков B.A. Корреспонденции «Екатеринбургской недели» // Екатеринбургская неделя. 1884. № 7, 15 февраля.

Вести отовсюду // Екатеринбургская неделя. 1880. № 49, 10 декабря.

Высочайше утвержденное (27 августа 1882 г.) положение Комитета Министров о временных мерах относительно периодической печати // ПСЗРИ. Собр. 3. Т. 2. Спб., 1886. № 1072. C. 390-391.

Высочайше утвержденные (12 мая 1862 г.) временные правила по цензуре // Полн. собр. законов Рос. Империи (ПСЗРИ). Собр. 2. Т. 37. Отд. 1. СПб., 1865. № 38270. С. 430 - 431.

Голова Е. Новый год // Екатеринбургская неделя. 1889. № 50, 31 декабря. Прибавление от 31 декабря.

Гросс T. «Кубарь, или бухгалтерия на том свете» // Екатеринбургская неделя. 1895. № 14, 9 апреля. URL: http://elib.uraic.ru/handle/123456789/4784

Корреспонденции Екатеринбургской недели // Екатеринбургская неделя. 1880. № 21, 27 мая.

Наши новогодние пожелания // Екатеринбургская неделя. 1880. № 1, 2 января.

Несколько слов о роли горнозаводского промысла в экономии государства // Екатеринбургская неделя. 1880. № 1, 2 января.

О даровании (6 апреля 1865 г.) некоторых облегчений и удобств отечественной печати // ПСЗРИ. Собр. 2. Т. 40, отд. 1. СПб., 1867. № 41988. С. 396.

О некоторых переменах и дополнениях (от 6 апреля 1865 г.) в действующих ныне цензурных постановлениях // ПСЗРИ. Собр. 2. Т. 40, отд. 1. СПб., 1867. № 41990. С. 397-406.

Пермское губернское земское собрание // Екатеринбургская неделя. 1884. № 7, 15 февраля.

Пермь // Екатеринбургская неделя. 1879. №10, 26 сентября.

Разрыв // Екатеринбургская неделя. 1894. № 49,11 декабря.

Российский государственный исторический архив (РГИА). Ф. 102. Департамент полиции. Оп. 1885. Д. 164. По поводу помещенных в № 2, 4 и 5 газеты «Екатеринбургская газета» статей тенденциозного характера; Ф. 776. Канцелярия Главного управления по делам печати. 
Оп. 6. Д. 190. По изданию г. Полковым газеты под названием «Екатеринбургская неделя»; Д. 191. По изданию газеты «Екатеринбургская неделя» 1887-1897; Оп. 12. Д. 61. Заявления члена Совета действительного статского советника Новикова; Ф. 945. Личный фонд Н.А. Иосса. Оп. 1. Д. 127. Письма А. и Н.А. Полковых Н.А. Иосса по поводу издания ими газеты «Екатеринбургская неделя» и листка объявлений в Екатеринбурге.

Шашков С.С. Земская смышляевщина (К десятилетнему юбилею Пермского земства) // Слово. Год второй, январь. СПб., 1879. С. $48-60$.

Штрихи общественной жизни // Екатеринбургская неделя. 1879. № 1, 25 июля; № 9, 19 сентября.

\section{Библиографический список}

Абросимов А.Г., Кузьмин В.Ю. Газеты XIX века // Электронная библиотека. URL: www.elbib.ru (дата обращения:10.10.2018).

Барышникова T.A. Частная провинциальная газета дореволюционной России как социокультурный феномен: Дис. ... канд. филол. наук. Челябинск, 2016. 185 с.

Бугаева С.Я. «Она писала в духе горных инженеров...» (Газета «Екатеринбургская неделя») // Изв. Урал. гос. ун-та. 1998. № 9. С. 136-141.

Буторин М.В. Провинциальная печать Европейского Севера России (правовые, организационные и социально-экономические аспекты). Архангельск: Б.и., 2011. 184 с.

Глинский Б.Б. Русская периодическая печать в провинции // Исторический вестник. 1898. № 1, т. 71. C. 292-333.

Грабельников А.А. Массовая информация в России: от первой газеты до информационного общества: Дис. ... докт. ист. наук. М., 2001. 349 с.

Гринченко Н.А., Патрушева Н.Г. Центральные учреждения цензурного ведомства (1804-1917) // Книжное дело в России в XIX - начале XX в.: Сб. науч. трудов. СПб.: Б.и., 2008. Вып. 14. C. $185-302$.

Есин Б.И. Русская дореволюционная газета: 1702-1917 гг.: Краткий очерк. М.: Изд-во Моск. унта, $1971.88 \mathrm{c}$.

Катков М.Н. О печати. М.: Печатня А.И. Снегиревой, 1905. 61 с.

Кройчик Л.Е. Провинциальная частная газета. Формирование концепции // Рос. провинц. частная газета / сост. Л.Е. Кройчик; под ред. Л.Е. Кройчика и Ю.А. Мандрики. Тюмень: Мандр и К 2004. C. 3-20.

Лихтин А.Н. История газет российской провинции в процессе взаимоотношений с органами власти: на материалах Оренбургского края XIX-XXI вв.: Дис. ... канд. ист. наук. Оренбург, 2005. $295 \mathrm{c}$.

Мандрика Ю.Л. Провинциальная частная печать: спорные вопросы становления периодики Сибири. Тюмень: РИЦ ТГАКИ, 2007. 103 с.

Морева O.B. «Новостей в городе нет. Все худо и хорошо». Повседневная жизнь уральцев во второй половине XIX - начале XX века // Урал. 2017. № 7. URL: https://magazines.russ.ru/ural/ 2017/7/novostei-v-gorode-net-vse-hudo-i-horosho.htmI (дата обращения:10.10.2018).

Павлов B.A. Периодические издания Урала XIX в. (краеведческий историкобиблиографический обзор). Свердловск:. Б.и., 1966. 126 с.

Павлов В.А. Очерки истории журналистики Урала. Т. 2, кн. 1 (1860 - нач. 1880-х гг.). Екатеринбург: Изд-во Урал. гос. ун-та, 1995. 180 с.

Павлов В.А. Очерки истории журналистики Урала. Т. 2, кн. 2 (1880 - 1890 гг.). Екатеринбург: Изд-во Урал. гос. ун-та, 1997. 240 с.

Патрушева Н.Г. Проблемы взаимоотношений деятелей печати с цензурой в конце 1860 -х начале 1880-х гг.// Книжное дело в России в XIX- начале XX в.: Сб. науч. трудов. СПб.: Б.и., 1996. Вып. 8. С. 29-50.

Патрушева Н.Г. История цензурных учреждений в России во вт. пол. ХІХ- начале XX в. // Книжное дело в России в XIX- начале XX в.: Сб. науч. трудов. СПб.: Б.и., 2000. Вып. 10. C. 7-48.

Чернуха В.Г. Главное управление по делам печати в 1865 - 1881 гг. // Книжное дело в России в XIX- начале XX в.: Сб. науч. трудов. СПб.: Б.и., 1992. Вып. 6. С. 20-40. 


\title{
FORMATION AND OPERATION OF THE FIRST PRIVATE NEWSPAPER "YEKATERINBURG WEEK"IN PERM PROVINCE IN THE LAST QUARTER OF THE $19^{\mathrm{TH}}$ CENTURY
}

\author{
G. N. Plotnikova, S. N. Plotnikov \\ Perm State University, Bukirev str., 15, 614990, Perm, Russia \\ sgp80@yandex.ru
}

The process of the formation of private media in the Perm province is analyzed using the example of the weekly political and literary newspaper Yekaterinburg Week (in 2019, it is 140 years since its establishment). The opening and operation of the media are considered, the main headings are characterized, the editorial staff's relations with the representatives of the official authorities (the governor, the Main Directorate of Press Affairs at the Ministry of Internal Affairs, the police department) are traced, and the public's ambiguous reaction to the published information is revealed. The authors state that the appearance of the first private newspaper had a significant impact on the public, not only in Yekaterinburg, but also in the province as a whole. The newspaper developed and improved feedback mechanisms with the population and authorities. This process took place under conditions of continuous control over the content of material published by the newspaper by censorship bodies, which often led to conflict situations with the editorial staff, personnel changes and the change of the owners of the media. The control by the representatives of the authorities also made it difficult to form an independent editorial position. A serious problem was the unprofitability of the newspaper. At the same time, well-known Ural writers and journalists were involved as correspondents, often offering their own vision of actual problems to readers. There was a criticism of local officials. A significant increase in circulation testified to the growing popularity of the media. Addressing the residents of the province as a whole, the newspaper was universal. Its activities stabilized the socio-political situation in the vast multi-ethnic Ural region. Yekaterinburg Week attracted readers to public life, educated them, contributed to shaping the sociocultural environment and civil beginnings in the Russian province in the last quarter of the $19^{\text {th }}$ century.

Key words: mass media, "Yekaterinburg week", censorship, General Directorate for Press Affairs, public, Perm province of the last quarter of the $19^{\text {th }}$ century.

\section{References}

Abrosimov, A.G., Kuzmin V.Yu. (2018), Gazety XIX veka [Newspapers of the XIX century,] available at: www.elbib.ru (accessed 10.10.2018).

Baryshnikova, T.A. (2016), Chastnaya provintsial'naya gazeta dorevolyutsionnoy Rossii kak sotsiokul'turnyy fenomen [Private provincial newspaper of pre-revolutionary Russia as a sociocultural phenomenon], PhD dissertation, Chelyabinsk, Russia, 185 p.

Bugaeva, S.Ya. (1998), “"She wrote in the spirit of mining engineers ...” (Yekaterinburg Week newspaper)», Izvestiya Ural'skogo gosudarstvennogo universiteta, № 9, pp. 136-141.

Butorin, M.V. (2011), Provintsial'naya pechat' Evropeyskogo Severa Rossii (pravovye, organizatsionnye i sotsial'no-ekonomicheskie aspekty) [The provincial seal of the European North of Russia (legal, organizational and socioeconomic aspects)], w.p., Arkhangelsk, Russia, 184 p.

Chernukha, V.G. (1992), "General Directorate of Press in 1865 - 1881", in Knizhnoe delo v Rossii v XIX-nachale XX v. [Book Business in Russia in the XIX - early XX century], Vol. 6, w.p., St. Petersburg, Russia, pp. $20-40$.

Esin, B.I. (1971), Russkaya dorevolyutsionnaya gazeta: 1702-1917 gg.: Kratkiy ocherk [Russian prerevolutionary newspaper: 1702-1917: A brief essay], Izd. Mosk. un-ta, Moscow, Russia, 88 p.

Glinsky, B.B. (1898), "Russian periodicals in the province”, Istoricheskiy vestnik, № 1, t. 71. p. 292-333.

Grabelnikov, A.A. (2001), Massovaya informatsiya v Rossii: ot pervoy gazety do informatsionnogo obshchestva [Mass information in Russia: from the first newspaper to the information society], PhD dissertation, Moscow, Russia, 349 p.

Grinchenko, N.A., Patrusheva, N.G. (2008), "Central institutions of the censorship department (1804-1917)", in Knizhnoe delo v Rossii v XIX-nachale XX v. [Book Business in Russia in the XIX - early XX century], Vol. 14., w.p., St. Petersburg, Russia, pp. 185-302.

Katkov, M.N. (1905), O pechati [About printing], Pechatnya A.I. Snegirevoy, Moscow, Russia, 61 p.

Kroychik, L.E. (2004), "Provincial private newspaper. Formation of the concept", in Kroychik, L.E. \& Yu.A. Mandrika (eds.), Rossiyskaya provintsialnaya chastnaya gazeta [Russian provincial private newspaper], Mandr i Ko, Tyumen, Russia, pp. 3-20.

Likhtin, A.N. (2005), Istoriya gazet rossiyskoy provintsii v protsesse vzaimootnosheniy s organami vlasti: na materialah Orenburgskogo kraya XIX-XXI vv. [The history of the newspapers of the Russian province in the pro- 
cess of relations with the authorities: on the materials of the Orenburg region of XIX - XXI centuries], PhD dissertation, Orenburg, Russia, 295 p.

Mandrika, Yu.L. (2007), Provintsial'naya chastnaya pechat': spornye voprosy stanovleniya periodiki Sibiri [Provincial private print: controversial issues of the formation of the periodicals of Siberia], RIC TGAKI, Tyumen, Russia, $103 \mathrm{p}$.

Moreva, O.V. (2017), "“There is no news in the city. Everything is bad and good". Daily life of the Urals in the second half of the XIX - early XX century», Ural, № 7, available at: https://magazines.russ.ru/ural/2017/7/novostei-vgorode-net-vse-hudo-i-horosho.htmI (accessed 10.10.2018)

Patrusheva, N.G. (1996), "Problems of relations between press activists and censorship in the late 1860s - early 1880s", in Knizhnoe delo v Rossii v XIX-nachale XX v. [Book Business in Russia in the XIX - early XX century], Vol. 8, B.I., St. Petersburg, Russia, pp. 29-50.

Patrusheva, N.G. (2000), "History of censorship institutions in Russia in Tues floor. XIX- early XX century", in Knizhnoe delo $v$ Rossii $v$ XIX-nachale XX v. [Book Business in Russia in the XIX - early XX century], Vol. 10, w.p., St. Petersburg, Russia, pp. 7-48.

Pavlov, V.A. (1966), Periodicheskie izdaniya Urala XIX v. (kraevedcheskiy i istoriko-bibliograficheskiy obzor) [Periodicals of the Ural XIX century (local history and bibliographic review)], w.p., Sverdlovsk, Russia, 126 p.

Pavlov, V.A. (1995), Ocherki istorii zhurnalistiki Urala. T. 2, kn. 1 (1860-nach. 1880-h gg.) [Essays on the history of journalism of the Urals. T. 2, Vol. 1 (1860 - beginning of the 1880s)], Izd-vo Ural. gos. un-ta, Yekaterinburg, Russia, 180 p.

Pavlov, V.A. (1997), Ocherki istorii zhurnalistiki Urala. T. 2, kn. 2 (1880 - 1890) [Essays on the history of journalism of the Urals. T. 2, Vol. 2 (1880 - 1890)], Izd-vo Ural. gos. un-ta, Yekaterinburg, Russia, 240 p. 